\title{
PENDIDIKAN KEWIRAUSAHAAN MELALUI PEMBINAAN KARAKTER BAGI SISWA SEKOLAH KEJURUAN DI KOTA SURAKARTA
}

\author{
Edhi Wasisto \\ Program Studi Manajemen, STIE AUB Surakarta
}

\begin{abstract}
The research aims to improve the knowledge, skills and motivation of entrepreneurship education for students and teachers in vocational schools (SMK) the city of Surakarta. The study consisted of three variables: (1) the intensity of the service model of entrepreneurship education; (2) entrepreneurial skills for students in Vocational High School .; (3) the effectiveness of services in entrepreneurship education through character education for students in Vocational High School. The research method is a survey, observation, interviews, questionnaires, documentation, and action (action research), giving the task to the subject of research and evaluation. The research location in the city of Surakarta. Given the technical constraints; limited funding and time of the study; as a test model specified the two schools; namely SMK SMK Bopkri 1 and 2. The research was conducted 6 months, beginning the month from April to October 2015. The quantitative data analysis using quantitative descriptive approach, while qualitative data using an interactive approach. Results: (1) obtained from the data base of potential Vocational High School. in the area of research related to the awareness and motivation of students in entrepreneurship; (2) obtained baseline prevalence of students who are interested in entrepreneurship education; (3) known to need assessment of the students who will participate in entrepreneurship education in schools; (4) can be prepared modules in entrepreneurship education material in Vocational High School; (5) can be arranged group accompanying teachers implementing entrepreneurship education in schools; (6) can be trained a number of 40 teachers accompanying the implementation of entrepreneurial skills education of students in the school; (7) can be produced prototype or tool entrepreneurship; (8) can be educated a number of 140 students in the field of entrepreneurial skills; (9) can be formed Productive Business Group (CTP) for students in the Vocational High School; (10) can be written journals of national terakriditasi; (11) can be written books on entrepreneurship education based character building for students at vocational schools. Keywords: Entrepreneurship education through character building vocational students
\end{abstract}

\begin{abstract}
Abstrak
Penelitian bertujuan meningkatkan pengetahuan, keterampilan, dan motivasi pendidikan kewirausahaan bagi siswa dan guru di Sekolah Menengah Kejuruan (SMK) wilayah Kota Surakarta. Penelitian terdiri dari tiga variabel: (1) intensitas pelayanan model pendidikan kewirausahaan; (2) keterampilan berwirausaha bagi siswa di Sekolah Menengah Kejuruan.; (3) efektivitas pelayanan pendidikan kewirausahaan melalui pendidikan karakter bagi siswa di Sekolah Menengah Kejuruan. Metode penelitian adalah survey, observasi, interview, angket, dokumentasi, dan tindakan (action research), pemberian tugas kepada subyek penelitian serta evaluasi. Lokasi penelitian di wilayah Kota Surakarta. Mengingat kendala teknis; keterbatasan dana dan waktu penelitian; sebagai ujicoba model ditentukan dua sekolah; yaitu SMK Bopkri 1 dan SMK Bopkri 2. Waktu penelitian dilaksanakan 6 bulan, yaitu dimulai bulan April - Oktober 2015. Analisis data kuantitatif menggunakan pendekatan deskriptif kuantitatif, sedangkan data kualitatif menggunakan pendekatan interaktif. Hasil penelitian: (1) diperoleh data dasar potensi Sekolah Menengah Kejuruan. di wilayah penelitian yang berkaitan dengan kesadaran dan motivasi siswa dalam berwirausaha; (2) diperoleh data dasar angka prevalensi siswa yang berminat dalam pendidikan kewirausahaan; (3) diketahui need asessment dari siswa yang akan mengikuti pendidikan kewirausahaan di sekolah; (4) dapat disusun modul materi pendidikan kewirausahaan di Sekolah Menengah Kejuruan; (5) dapat disusun kelompok guru pendamping pelaksanaan pendidikan kewirausahaan di sekolah; (6) dapat dilatih sejumlah 40 guru pendamping pelaksanaan
\end{abstract}


pendidikan keterampilan berwirausaha siswa di sekolah; (7) dapat dihasilkan prototype atau alat kewirausahaan; (8) dapat dididik sejumlah 140 siswa dalam bidang keterampilan berwirausaha; (9) dapat dibentuk Kelompok Usaha Produktif (KUP) bagi siswa di lingkungan Sekolah Menengah Kejuruan; (10) dapat ditulis jurnal terakriditasi nasional; (11) dapat ditulis buku tentang pendidikan kewirausahaan berbasis pembinaan karakter bagi siswa di sekolah kejuruan.

Kata kunci: Pendidikan kewirausahaan melalui pembinaan karakter siswa SMK

\section{PENDAHULUAN}

Pendidikan di Indonesia saat ini cenderung lebih mengedepankan penguasaan aspek keilmuan, kecerdasan, dan mengabaikan pendidikan karakter. Pengetahuan tentang kaidah moral yang didapatkan dalam pendidikan moral atau etika di sekolah saat ini semakin ditinggalkan (Binsar A. Hutabarat, 2010). Kebanyakan pelaksana pendidikan mulai kurang memperhatikan lagi bagaimana pendidikan itu dapat berdampak terhadap perilaku seseorang. Itulah cacat terbesar pendidikan gagal untuk menghadirkan generasi anak-anak bangsa yang berkarakter kuat.

Ciri-ciri karakter yang diinginkan dalam tujuan pendidikan untuk membangun jiwa kewirausahaan di sekolah, seperti kejujuran, kesopanan, keberanian, ketekunan, kesetiaan, pengendalian diri, simpati, toleransi, keadilan, menghormati harga diri individu, tanggung jawab untuk kebaikan umum dan lain-lain. Lebih spesifiknya dikemukakan Thomas Lickona (2006), pendidikan yang mengambangkan karakter adalah upaya yang dilakukan pendidikan untuk membantu anak didik supaya mengerti, kepedulian, dan bertindak berdasarkan nilai-nilai etika. Anak didik bisa menilai mana yang benar, sangat memedulikan tentang yang benar, dan melakukan apa yang mereka yakini sebagai yang benar, walaupun ada tekanan dari luar dan godaan dari dalam. Pada sisi lain, permasalahan yang muncul jumlah angka pengangguran di Indonesia selalu meningkat setiap tahunnya. Peningkatan angka pengangguran tersebut selalu dikaitkan dengan sekolah (lembaga pendidikan) selaku lembaga yang memproduk calon-calon tenaga kerja tersebut. Para pengelola sekolah (kepala sekolah, guru) menjadi sorotan semua pihak baik itu pengamat pendidikan, politisi, bahkan pemerintah sendiri karena dianggap tidak dapat menghasilkan tamatan-tamatan yang berkualitas. Pengangguran ini terjadi karena lapangan pekerjaan yang tersedia tidak mampu menampung jumlah angkatan kerja yang ada, atau dengan kata lain laju pertambahan tenaga kerja tidak sebanding dengan pertumbuhan lapangan pekerjaan. Data dari BPS (2010), satu di antara 10 angkatan kerja kini berstatus penganggur. Padahal menurut penelitian, setiap pertumbuhan ekonomi 1 persen hanya mampu menciptakan sebanyak sekitar 265.000 lapangan kerja baru. Dengan pertumbuhan ekonomi Indonesia yang berkisar antara 6 persen, maka hanya tersedia sebanyak sekitar 1.590.000 lapangan kerja baru.

Kurikulum yang diterapkan di sekolah sekarang ini cenderung teoritis, mungkin turut memberikan kontribusi kepada ketidaksiapan lulusan untuk memilih karir kerja mandiri (self-employment) atau berwirausaha karena mereka hanya disiapkan untuk melanjutkan atau masuk perguruan tinggi. Demikian pula lulusan perguruan tinggi pada umumnya dipersiapkan untuk bekerja menjadi karyawan. Memilih karir berwirausaha merupakan kasus luar biasa, kecuali bagi mereka yang memiliki latar belakang keluarga wirausaha terutama dari kalangan warga etnis keturunan. Oleh sebab itu pendidikan kewirausaahaan di Sekolah Menengah Kejuruan mungkin merupakan bagian dari solusi mengatasi masalah pengangguran. Sebenarnya angka pengangguran tersebut tidak sepenuhnya diakibatkan dengan kurangnya lapangan pekerjaan yang tersedia, akan tetapi juga berasal dari faktor internal para calon tenaga kerja itu sendiri. Menurut hemat penulis ada beberapa faktor penyebabnya yaitu: (1) sebagian besar lulusan sekolah menengah ataupun perguruan tinggi menginginkan pekerjaan-pekerjaan di sektor formal seperti menjadi Pegawai Negeri Sipil. Sedangkan pemerintah telah memprogramkan bahwa pertumbuhan jumlah Pegewai Negeri adalah 0 persen. Kalaupun ada penerimaan dan pengangkatan Pegawai Negeri baru, itu hanyalah penyisipan untuk menggantikan mereka-mereka yang sudah memasuki usia pensiun, dan itu pun jumlahnya sangat sedikit; (2). Sebagian para calon tenaga kerja itu tidak memiliki bekal pendidikan kewirausahaan (entrepreneurship), sehingga mereka cenderung mencari atau mengharapkan pekerjaan dari orang lain dan bukan sebaliknya berupaya mengembangkan potensi dirinya serta berusaha menciptakan lapangan pekerjaan untuk orang lain. 
Berdasarkan fenomena di atas, maka menurut hemat peneliti salah satu upaya yang dapat dilakukan oleh sekolah untuk meminimalisasi pengangguran tersebut adalah memberikan Pendidikan Kewirausahaan (entrepreneurship) semenjak dini. Sehingga para siswa memiliki bekal spirit yang tinggi yaitu mandiri, berani menanggung resiko dan mampu memanfaatkan peluang sekecil apapun serta memiliki jiwa tidak mudah menyerah.

Berbagai kondisi ini akan mengganggu ekonomi dan psikologis masyarakat. Post Traumatic Stress Disorders adalah dampak psikologis bagi para korban, terutama pada anak-anak sekolah. Mereka akan selalu teringat dengan peristiwa buruk yang telah dialaminya. Gejala yang timbul adalah sering menangis, mudah marah dan berteriak, mimpi buruk, sulit tidur, tidak mau makan, tidak mau bermain. Keadaan ini akan menjadi lebih berat bila ditambah dengan beban psikologis kehilangan orangtua atau saudara. Dalam keadaan berat bisa mengakibatkan perasaan depresi yang lebih berat seperti hendak melakukan bunuh diri dan gangguan kejiwaan lain yang berkepanjanagan. Bila hal ini tidak ditangani segera akan dapat mengganggu kesehatan dan proses tumbuh dan berkembangnya anak, juga tidak kalah pentingnya dalam proses pembelajaran. Usia anak sekolah daya tahan tubuhnya rentan, ditambah gangguan asupan gizi, trauma panas, hujan dan dingin, serta trauma psikis akan memperburuk keadaan. Berbagai keadaan tersebut akan mengakibatkan daya tahan tubuh menurun dan mudah terserang penyakit dan ancaman jiwa paska bencana erupsi gunung berapi.

Mencermati berbagai permasalahan tersebut di atas, peneliti akan mencoba menawarkan ujicoba Pengembangan Model Kebijakan Pendidikan Kewirausahaan berbasis Karakter bagi Siswa di Sekolah khususnya di tingkat SMK di wilayah Kota Surakarta. Rumusan masalah dalam penelitian ini adalah: (1) bagaimana intensitas kebijakan sekolah dan pemerintah (khususnya dinas pendidikan) dalam pelayanan pengembangan model pendidikan kewirausahaan di sekolah berbasis karakter di wilayah kota Surakarta; (2) bagaimana keterampilan kewirausahaan siswa SMK, dalam hal; (a) keakuratan kerja dengan hasil yang tepat; (b) ketepatan waktu bekerja; (c) kesempurnaan kerja dengan hasil baik; (3) bagaimana efektivitas pelayanan model pendidikan kewirausahaan bagi siswa SMK, dilihat dari aspek: (a) tingkat penguasaan keterampilan usaha; (b) kualitas produk yang dihasilkan; (c) pasar produk. Mencermati uraian rumusan masalah tujuan dalam penelitian ini adalah: (1) menumbuh-kembangkan budaya kewirausahaan di dalam lingkungan SMK untuk mendorong para warga sekolah khususnya siswa, guru, dan warga sekolah agar memiliki jiwa kewirausahaan dan mampu menjadi wirausahawan yang berwawasan jauh ke depan dan luas berbasis ilmu, keterampilan, dan nilai karakter yang telah diperolehnya; (2) mendorong pengembangan kompetensi kewirausahaan, dalam hal kreativitas dan inovasi, serta pemanfaatan hasil praktik pembelajaran menjadi perangkat yang dapat digunakan oleh siswa, guru, dan warga sekolah yang bernilai karakter, dan komersial, (3) mewujudkan sinergi potensi sekolah dengan potensi industri/usaha kecil menengah di lingkungan sekolah; (4) mendorong pemulihan ekonomi Indonesia melalui penanggulangan kemiskinan dan penyediaan lapangan kerja dengan tumbuhnya wirausaha baru yang kuat, baik dari segi kualitas produk dan jasa maupun dari segi pemasarannya, (4) sesuai dengan keunggulan lokal wilayah sekolah, menumbuh-kembangkan kegiatan sekolah yang mendorong terwujudnya income generating di lingkungan SMK dalam mengantisipasi diberlakukannya kebijakan, otonomi daerah, dan sekolah.

\section{KAJIAN PUSTAKA}

Pengertian karakter menurut Pusat Bahasa Depdiknas adalah "bawaan, hati, jiwa, kepribadian, budi pekerti, perilaku, personalitas, sifat, tabiat, temperamen, watak". Adapun berkarakter adalah berkepribadian, berperilaku, bersifat, bertabiat, dan berwatak". Ki Tyasno Sudarto (2007), karakter mengacu kepada serangkaian sikap (attitudes), perilaku (behaviors), motivasi (motivations), dan keterampilan (skills). Karakter berasal dari bahasa Yunani yang berarti "to mark" atau menandai dan memfokuskan bagaimana mengaplikasikan nilai kebaikan dalam bentuk tindakan atau tingkah laku, sehingga orang yang tidak jujur, kejam, rakus dan perilaku jelek lainnya dikatakan orang berkarakter jelek. Sebaliknya, orang yang perilakunya sesuai dengan kaidah moral disebut dengan berkarakter mulia.

Karakter mulia berarti individu memiliki pengetahuan tentang potensi dirinya, yang ditandai dengan nilai-nilai seperti reflektif, percaya diri, rasional, logis, kritis, analitis, kreatif dan inovatif, mandiri, hidup sehat, bertanggung jawab, cinta ilmu, sabar, berhati-hati, rela berkorban, pemberani, dapat dipercaya, jujur, menepati janji, adil, rendah hati, malu berbuat salah, pemaaf, berhati lembut, setia, bekerja keras, tekun, ulet/gigih, teliti, berinisiatif, berpikir positif, disiplin, antisipatif, inisiatif, visioner, bersahaja, bersemangat, 
dinamis, hemat/efisien, menghargai waktu, pengabdia/ dedikatif, pengendalian diri, produktif, ramah, cinta keindahan (estetis), sportif, tabah, terbuka, tertib. Individu juga memiliki kesadaran untuk berbuat yang terbaik atau unggul, dan individu juga mampu bertindak sesuai potensi dan kesadarannya tersebut. Karakteristik adalah realisasi perkembangan positif sebagai individu (intelektual, emosional, sosial, etika, dan perilaku).

Pendidikan karakter adalah suatu sistem penanaman nilai-nilai karakter kepada warga sekolah yang meliputi komponen pengetahuan, kesadaran atau kemauan, dan tindakan untuk melaksanakan nilai-nilai tersebut. Pendidikan karakter dapat dimaknai sebagai "the deliberate use of all dimensions of school life to foster optimal character development". Dalam pendidikan karakter di sekolah, semua komponen (pemangku pendidikan) harus dilibatkan, termasuk komponen-komponen pendidikan itu sendiri, yaitu isi kurikulum, proses pembelajaran dan penilaian, penanganan atau pengelolaan mata pelajaran, pengelolaan sekolah, pelaksanaan aktivitas atau kegiatan kokurikuler, pemberdayaan sarana prasarana, pembiayaan, dan ethos kerja seluruh warga sekolah/ lingkungan. Di samping itu, pendidikan karakter dimaknai sebagai suatu perilaku warga sekolah yang dalam menyelenggarakan pendidikan harus berkarakter.

Ropke (1989), pendidikan karakter dimaknai sebagai berikut: "character educa-tion is the deliberate effort to help people understand, care about, and act upon core ethical values. When we think about the kind of character we want for our children, it is clear that we want them to be able to judge what is right, care deeply about what is right, and then do what they believe to be right, even in the face of pressure from without and temptation from within". Lebih lanjut dijelaskan bahwa pendidikan karakter adalah segala sesuatu yang dilakukan guru, yang mampu mempengaruhi karakter peserta didik. Guru membantu membentuk watak peserta didik. Hal ini mencakup keteladanan bagaimana perilaku guru, cara guru berbicara atau menyampaikan materi, bagaimana guru bertoleransi, dan berbagai hal terkait lainnya.

Maksum dan Luluk YR. (2004), pendidikan karakter memiliki esensi dan makna yang sama dengan pendidikan moral dan pendidikan akhlak. Tujuannya adalah membentuk pribadi anak, supaya menjadi manusia yang baik, warga masyarakat, dan warga negara yang baik. Adapun kriteria manusia yang baik, warga masyarakat yang baik, dan warga negara yang baik bagi suatu masyarakat atau bangsa, secara umum adalah nilai-nilai sosial tertentu, yang banyak dipengaruhi oleh budaya masyarakat dan bangsanya. Oleh karena itu, hakikat dari pendidikan karakter dalam konteks pendidikan di Indonesia adalah pedidikan nilai, yakni pendidikan nilai-nilai luhur yang bersumber dari budaya bangsa Indonesia sendiri, dalam rangka membina kepribadian generasi muda.

Pendidikan karakter berpijak dari karakter dasar manusia, yang bersumber dari nilai moral universal (bersifat absolut) yang bersumber dari agama yang juga disebut sebagai the golden rule. Pendidikan karakter dapat memiliki tujuan yang pasti, apabila berpijak dari nilai-nilai karakter dasar tersebut. Menurut para ahli psikolog, beberapa nilai karakter dasar tersebut adalah: cinta kepada Allah dan ciptaan-Nya (alam dengan isinya), tanggung jawab, jujur, hormat dan santun, kasih sayang, peduli, dan kerjasama, percaya diri, kreatif, kerja keras, dan pantang menyerah, keadilan dan kepemimpinan; baik dan rendah hati, toleransi, cinta damai, dan cinta persatuan. Pendapat lain mengatakan bahwa karakter dasar manusia terdiri dari: dapat dipercaya, rasa hormat dan perhatian, peduli, jujur, tanggung jawab; kewarganegaraan, ketulusan, berani, tekun, disiplin, visioner, adil, dan punya integritas. Penyelenggaraan pendidikan karakter di sekolah harus berpijak kepada nilai-nilai karakter dasar, yang selanjutnya dikembangkan menjadi nilai-nilai yang lebih banyak atau lebih tinggi (yang bersifat tidak absolut atau bersifat relatif) sesuai dengan kebutuhan, kondisi, dan lingkungan sekolah itu sendiri.

Para pakar pendidikan pada umumnya sependapat tentang pentingnya upaya peningkatan pendidikan karakter pada jalur pendidikan formal. Namun demikian, ada perbedaan-perbedaan pendapat di antara mereka tentang pendekatan dan modus pendidikannya. Berhubungan dengan pendekatan, sebagian pakar menyarankan penggunaan pendekatan-pendekatan pendidikan moral yang dikembangkan di negara-negara barat, seperti: pendekatan perkembangan moral kognitif, pendekatan analisis nilai, dan pendekatan klarifikasi nilai. Sebagian yang lain menyarankan penggunaan pendekatan tradisional, yakni melalui penanaman nilainilai sosial tertentu dalam diri peserta didik. Berdasarkan grand design yang dikembangkan Kemendiknas (2010), secara psikologis dan sosial kultural pembentukan karakter dalam diri individu merupakan fungsi dari seluruh potensi individu manusia (kognitif, afektif, konatif, dan psikomotorik) dalam konteks interaksi sosial kultural (dalam keluarga, sekolah, dan masyarakat) dan berlangsung sepanjang hayat. Konfigurasi karakter dalam konteks totalitas proses psikologis dan sosial-kultural tersebut dapat dikelompokkan dalam: Olah Hati (Spiritual and emotional development), Olah pikir (intellectual development), Olah raga dan 
kinestetik (Physical and kinestetic development), dan Olah rasa dan karsa (Affective and Creativity development) yang secara diagramatik dapat digambarkan sebagai berikut.

Para pakar telah mengemukakan berbagai teori tentang pendidikan moral. Hersh Richard, et al. (1980), di antara berbagai teori yang berkembang, ada enam teori yang banyak digunakan; yaitu: pendekatan pengembangan rasional, pendekatan pertim-bangan, pendekatan klarifikasi nilai, pendekatan pengem-bangan moral kognitif, dan pendekatan perilaku sosial. Berbeda dengan klasifikasi tersebut, Kao, John, (1989) mengklasifikasikan berbagai teori yang, berkembang menjadi tiga, yakni: pendekatan kognitif, pendekatan afektif, dan pendekatan perilaku. Klasifikasi didasarkan pada tiga unsur moralitas, yang biasa menjadi tumpuan kajian psikologi, yakni: perilaku, kognisi, dan afeksi.

Arismunandar, (2006) lebih panjang merumuskan tentang karakter sebagai konsepsi dari apa yang diinginkan, yang memengaruhi pilihan terhadap cara, tujuan antara dan tujuan akhir tindakan. Maksum dan Luluk YR., (2004) mengungkapkan bahwa definisi nilai karakter memiliki banyak implikasi terhadap pemaknaan nilai-nilai budaya, dalam pengertian lebih spesifik implikasi yang dimaksud adalah: (1) nilai karakter merupakan konstruk yang melibatkan proses kognitif (logis dan rasional) dan proses katektik (ketertarikan atau penolakan menurut kata hati); (2) nilai krakter selalu berfungsi secara potensial, tetapi selalu tidak bermakna apabila diverbalisasi; (3) apabila hal itu berkenan dengan budaya, nilai karakter diungkapkan dengan cara yang unik oleh individu atau kelompok.

Pendidikan nilai karakter dapat menjadi sarana penting dalam menangkal pengaruh-pengaruh negatif yang terjadi dalam kehidupan masyarakat global dewasa ini. Sejalan dengan derap laju perkembangan budaya kewirausahaan dan laju perkembangan ilmu pengetahuan, teknologi dan seni, serta arus reformasi sekarang ini, pendidikan nilai karakter semakin dirasa penting sebagai salah satu alat pengendali tercapainya tujuan pendidikan nasional secara utuh. Kaitannya dengan nilai karakter diartikan sebagai (1) kualitas dan kuantitas reaksi terhadap diri sendiri, orang lain, maupun situasi terntentu; (2) watak, akhlak, ciri psikologis. Magnis Suseno Frans (1987), ciri-ciri psikologis yang dimiliki pelaku wirausaha pada lingkup pribadi, secara evolutif akan berkembang menjadi ciri kelompok dan lebih luas lagi menjadi ciri sosial. Ciri psikologis individu akan memberi warna dan corak identitas kelompok dan pada tatanan makro akan menjadi ciri psikologis atau karakter suatu pelaku kewirausahaan. Pembentukan karakter suatu bangsa berproses secara dinamis sebagai suatu fenomena sosio-ekologis.

Sebagai identitas atau jati diri suatu bangsa, karakter merupakan nilai dasar perilaku yang menjadi acuan tata nilai interaksi antar manusia (when character is lost then every ting is lost). Secara universal berbagai karakter dirumuskan sebagai nilai hidup bersama berdasarkan atas pilar: kedamaian (peace), menghargai (respect), kerjasama (cooperation), kebebasan (fredom), kebahagiaan (happinnes), kejujuran (honesty), kerendahan hati (humility), kasih sayang (love), tanggung jawab (responsibility), kesederhanaan (simplicty), toleransi (tolerance) dan peratuan (unity). Filosofis karakter dikemukakan oleh Ketua Umum Majelis Hukum Taman Siswo Ki Tyasno Sudarto (2007) yaitu: (1) mahayu hayuning saliro (bagaimana hidup untuk meningkatkan kualitas diri); (2) mahayu hayuning bongso (bagaimana berjuang untuk negara dan bangsa); (3) mahayu hayuning bawana (bagaimana membangun kesejahteraan dunia).

Sebagai pelaku kewirausahaan, untuk mencapai tatanan Tri Rahayu tersebut, manusia harus memahami, menghayati, serta melaksanakan tugasnya sebagai manusia yang tercantum dalam Tri Satya Brata: (1) rahayuning bawono kapurbo waksitaning manungso (kesejahteraan dunia tergantung pada manusia yang memiliki ketajaman rasa); (2) dharmaning manungso mahanani rahayuning negara (tugas utama dalam menjaga keselamatan negara); (3) rahayuning manungso dumadi karana kemanung-sane (keselamatan manusia ditentukan tata perilakunya). Nilai-nilai karakter pendekatan akademis yang dimaksudkan adalah iman, taqwa, berakhlak mulia, berilmu, jujur, disiplin, demokratis, adil, bertanggung jawab, orientasi pada keunggulan, gotong royong dan lainnya. Thoby Mutis. (1995) dalam upaya untuk mengaktualisasikan nilai karakter, dituntut peran penting dari Kepala Sekolah dalam program peningkatan kapasitas, khususnya perannya sebagai: (1) character builders, yaitu membangun kembali karakter positif para pendidik dengan menjunjung nilai-nilai moral di atas kepentingan sesaat dan menginternalisasikan pada kegiatan dan aktifitasnya sehari-hari; (2) character enabler, yaitu pemberdayaan secara terus menerus karakter pendidik dengan bersedia menjadi role model dari pengembangan karakter di 
lingkungannya; dan (3) character enginer, yaitu terus menerus melakukan pembelajaran pengem-bangan karakter yang menuntut adanya modifikasi dan rekayasa yang tepat disesuaikan dengan perkembangan jaman.

Mas'ud Machffoedz (2002), program peningkatan kapasitas, khususnya Kepala Sekolah perlu berperan dalam pembangunan karakter aparatur pejabat yang profesional melalui intervensi pada tiga tingkatan, yaitu: (1) tingkat sistem, seperti kebijakan dan pengaturan kerangka kerja yang relevan; (2) tingkat kelembagaan, seperti struktur organisasi, proses pengambilan keputusan dan prosedur lain, sistem informasi manajemen dan hubungan antar organisasi lembaga; (3) tingkat individual, seperti kompetensi, keterampilan dan kualifikasi individu, pengetahuan, sikap, etika dan motivasi personil. Sekolah adalah komponen bangsa yang paling strategis posisinya dalam memainkan proses tranformasi karakter dan tata nilai di tengah-tengah derasnya liberalisme era globalisasi.

Dalam konteks pengembangan kewirausahaan, fungsi dan tujuan pendidikan nasional sebagaimana dijelaskan dalam Undang-Undang Sistem Pendidikan Nasional No 20 tahun 2003 bab II pasal 3 sebagai berikut: Pendidikan nasional berfungsi mengembangkan kemampuan dan membentuk watak serta peradaban bangsa yang bermartabat dalam rangka mencerdaskan kehidupan bangsa bertujuan untuk berkembangnya potensi peserta didik agar menjadi manusia yang beriman dan bertakwa kepada Tuhan Yang Maha Esa, berakhlak mulia, sehat, berilmu, cakap, kreatif, mandiri dan menjadi warga negara yang demokratis serta bertanggung jawab. Rusman Hakim (1998), terdapat beberapa pendekatan akademis dalam membangun jiwa kewirausahaan di sekolah melalui nilai karakter yang dapat dijabarkan lebih jauh oleh perguruan tinggi dalam rangka mengembangkan pendidikan yang berbasis nilai karakter dan budaya: (1) pendekatan perkembangan kognitif; (2) pendekatan analisis nilai; (3) pendekatan klarifikasi nilai; (4) pendekatan pembelajaran berbuat.

Tujuan yang ingin dicapai oleh pendekatan ini ada dua hal yang utama: (1) membantu Kepala Sekolah dalam membuat pertimbangan moral yang lebih kompleks berdasarkan kepada nilai karakter yang lebih tinggi; (2) mendorong Kepala Sekolah untuk mendiskusikan alasan-alasannya ketika memilih nilai karakter dan posisinya dalam membangun jiwa kewirausahaan di sekolah. Pendekatan analisis nilai (values analysis approach) memberikan penekanan pada perkembangan kemampuan Kepala Sekolah untuk berpikir logis, dengan cara menganalisis masalah yang berhubungan dengan nilai-nilai sosial. Jika dibandingkan dengan pendekatan perkembangan kognitif, salah satu perbedaan penting antara keduanya bahwa pendekatan analisis nilai lebih menekankan pada pembahasan masalah-masalah yang memuat nilai-nilai sosial. Adapun pendekatan perkembangan kognitif memberi penekanan pada dilema moral yang bersifat perseorangan.

Terdapat dua tujuan utama pendidikan karakter menurut pendekatan ini: (1) membantu Kepala Sekolah untuk menggunakan kemampuan berpikir logis dan penemuan ilmiah dalam meng-analisis masalahmasalah membangun jiwa kewirausahaan di sekolah, yang berhubungan dengan nilai karakter tertentu; (2) membantu Kepala Sekolah untuk menggunakan proses berpikir rasional dan analitik, dalam menghubunghubungkan dan meru-muskan konsep tentang nilai-nilai karakter mereka dalam membangun jiwa kewirausahaan di sekolah. Pendekatan klarifikasi nilai (values clarification approach) memberi penekanan pada usaha membantu Kepala Sekolah dalam mengkaji perasaan dan perbuatannya sendiri, untuk meningkatkan kesadaran mereka tentang nilai-nilai karakter mereka sendiri. Buchari (2006), tujuan pendidikan nilai karakter menurut pendekatan ini ada tiga: (1) membantu Kepala Sekolah untuk menyadari dan meng-identifikasi nilai-nilai mereka sendiri serta nilai-nilai dan karakter orang lain; (2) membantu Kepala Sekolah, supaya mereka mampu berkomunikasi secara terbuka dan jujur dengan orang lain, berhubungan dengan nilai-nilainya sendiri; (3) membantu Kepala Sekolah, supaya mereka mampu menggunakan secara bersama-sama kemampuan berpikir rasional dan kesadaran emosional, untuk memahami perasaan, dan pola tingkah laku mereka sendiri. Pendekatan pembelajaran berbuat (action learning approach) memberi penekanan pada usaha memberikan kesempatan kepada Kepala Sekolah untuk melakukan perbuatan-perbuatan moral, baik secara perseorangan maupun secara bersama-sama dalam suatu kelompok. Ki Tyasno Sudarto, (2007), terdapat dua tujuan utama pendidikan moral berdasarkan kepada pendekatan ini: (1) memberi kesempatan kepada Kepala Sekolah untuk melakukan perbuatan moral, baik 
secara perseorangan mahupun secara bersama-sama, berdasarkan nilai-nilai mereka sendiri; (2) mendorong Kepala Sekolah untuk melihat diri mereka sebagai makhluk individu dan makhluk sosial dalam pergaulan dengan sesama, yang tidak memiliki kebebasan sepenuhnya, melainkan sebagai warga dari suatu masyarakat, yang harus mengambil bagian dalam suatu proses demokrasi.

Perkembangan nilai karakter menurut pendekatan ini dilihat sebagai perkembangan tingkat berpikir dalam membuat pertimbangan moral, dari suatu tingkat yang lebih rendah menuju suatu tingkat yang lebih tinggi. Tujuan yang ingin dicapai oleh pendekatan ini ada dua hal yang utama. Pertama, membantu pelaku kewirausahaan dalam membuat pertimbangan nilai karakter yang lebih kompleks berdasarkan kepada nilai yang lebih tinggi. Kedua, mendorong pelaku kewirausahaan untuk mendiskusikan alasan-alasannya ketika memilih nilai karakter dan posisinya ketika Kepala Sekolah melakukan pembinaan dalam pengembangan budaya kewirausahaan di lingkungan sekolah.

Pendekatan analisis nilai (values analysis approach) memberikan penekanan pada perkembangan kemampuan Kepala Sekolah untuk berpikir logis, dengan cara menganalisis masalah yang berhubungan dengan membangun jiwa kewirausahaan di lingkungan sekolah. Jika dibandingkan dengan pendekatan perkembangan kognitif, salah satu perbedaan penting antara keduanya bahwa pendekatan analisis nilai karakter lebih menekankan pada pembahasan masalah-masalah yang memuat nilai-nilai sosial. Adapun pendekatan perkembangan kognitif memberi penekanan pada dilema moral yang bersifat perseorangan. Terdapat dua tujuan utama pendidikan nilai karakter menurut pendekatan ini; (1) membantu Kepala Sekolah untuk menggunakan kemampuan berpikir logis dan penemuan ilmiah dalam menganalisis masalah-masalah membangun jiwa kewirausahaan, yang berhubungan dengan nilai karakter tertentu; (2) membantu Kepala Sekolah untuk menggunakan proses berpikir rasional dan analitik, dalam menghubungkan dan merumuskan konsep tentang nilai-nilai karakter.

Pendekatan klarifikasi nilai (values clarification approach) memberi penekanan pada usaha membantu Kepala Sekolah dalam mengkaji perasaan dan perbuatannya sendiri, untuk meningkatkan kesadaran mereka tentang nilai-nilai mereka sendiri. Silvia Herawaty, (1998) tujuan pendidikan nilai karakter menurut pendekatan ini ada tiga: (1) membantu Kepala Sekolah untuk menyadari dan mengidentifikasi nilai-nilai mereka sendiri serta karakter orang lain; (2) membantu Kepala Sekolah, supaya mereka mampu berkomunikasi secara terbuka dan jujur dengan orang lain, berhubungan dengan karakteristiknya sendiri; (3) membantu Kepala Sekolah, supaya mereka mampu menggunakan secara bersama-sama kemampuan berpikir rasional dan kesadaran emosional, untuk memahami perasaan, nilai-nilai karakter.

Banyak referensi dan literatur yang membahas pemahaman tentang kewira-usahaan. Dikemukakan Suyana (2003) melalui bukunya yang berjudul "kewirausahaan, pedoman praktis, kiat dan proses menuju sukses". Kewirausahaan adalah kemampuan kreatif dan inovatif yang dijadikan dasar, kiat dan sumber daya untuk mencari peluang menuju sukses. Inti dari kewirausahaan adalah kemampuan untuk menciptakan sesuatu yang baru dan berbeda (creatif new and different) melalui berfikir kreatif dan bertindak inovatif untuk menciptakan peluang. Bagaimana membangun jiwa kewirausahaan (interpreneurship) dapat diuraikan bahwa memahami kewirausahaan maka kepala sekolah harus memahami terlebih dahulu bagaimana muatan konsep kewirausahaan tersebut secara praktis dan menerapkannya secara teknis. Membangun jiwa kewirausahaan haruslah dimulai dengan kemauan kreatif dan inovatif kepala sekolah untuk mencapai suatu tujuan pada sekolah yang dipimpinnya. Banyak orang yang berhasil dan sukses karena memiliki kemampuan berfikir kreatif dan inovatif. Hal tersebut penting untuk dipahami mengingat selama ini dalam kehidupan sehari-hari, masih banyak orang yang menafsirkan dan memandang bahwa kewirausahaan identik dengan apa yang dimiliki dan dilakukan oleh "usahawan" atau "wiraswasta". Padahal jiwa kewirausahaan (interpreneurship) tidak hanya dimiliki oleh usahawan akan tetapi dapat dimiliki oleh setiap orang yang berfikir kreatif dan bertindak inovatif baik kalangan pemerintah, mahasiswa, dosen, guru termasuk kepala sekolah.

Untuk mendorong berkembangnya jiwa kewirausahaan, maka kepala sekolah haruslah memiliki kompetensi. Kompetensi tersebut merupakan syarat utama bagi kepala sekolah yang ingin melakukan proses perjalanan kreativitas berfikir dan inovasi tentang keinginan yang diharapkannya untuk kemajuan sekolah. Kompetensi adalah seseorang yang memiliki ilmu pengetahuan, keterampilan dan kualitas individu yang 
meliputi sikap, motivasi, nilai serta tingkah laku yang diperlukan untuk melaksanakan pekerjaan/kegiatan.. Mas'ud Machfoedz (2004) beliau memberikan pemahaman wirausaha tidak hanya memerlukan pengetahuan tapi juga keterampilan. Keterampilan tersebut diantaranya keterampilan manajerial (managerial skill), keterampilan konsep-tual (conceptual skill) dan keterampilan memahami, mengerti, berkomunikasi dan berelasi (human skill) dan keterampilan merumuskan masalah dan mengambil keputusan (decicion making skill), keterampilan mengatur dan menggunakan waktu (time management skill) dan keterampilan teknik lainnya secara spesifik.

Ide berwirausaha akan menjadi peluang apabila kepala sekolah bersedia melakukan evaluasi terhadap peluang secara terus menerus melalui proses penciptaan sesuatu yang baru dan berbeda, mengamati pintu peluang, menganalisis proses secara mendalam dan memperhitungkan risiko yang mungkin terjadi. Oleh karenanya maka kepala sekolah harus memiliki ciri dalam dirinya, yaitu percaya diri (self confidence), berorientasi pada tugas dan hasil, keberanian mengambil risiko, berorientasi pada masa depan dan orisinil. Ciri-ciri tersebut perlu dikembangkan secara lebih detail dan terperinci untuk kemajuan sekolah. Bahwa keberhasilan kepala sekolah memimpin sekolah didasari atas sikap dan persepsinya sendiri tentang apa yang dikerjakannya. Jika sikap dan persepsinya positif tentang apa yang dilakukannya, maka dengan sendirinya motivasi dan kreativitas serta inovasi akan muncul seiring dengan harapan untuk mencapai tujuan yang diinginkan.

Dalam mencari pelanggan, bisnis kecil kini tidak lagi dibatasi dalam ruang lingkup Negara sendiri. Pergeseran dalam ekonomi global yang dramatis telah membuka pintu ke peluang bisnis yang luar biasa bagi para wirausahawan yang bersedia menggapai seluruh dunia. Kejadian dunia seperti runtuhnya tembok Berlin, revolusi di negara-negara baltik Uni Soviet dan hilangnya hambatan perdagangan sebagai hasil perjanjian Masyarakat Ekonomi Eropa, telah membuka sebagian besar pasar dunia bagi para wirausahawan. Peluang Internasional akan terus berlanjut dan tumbuh dengan cepat pada abad ke 21. Faktor yang mendukung pembahasan ini adalah faktor pendidikan kewira-usahaan. Di luar negeri banyak universitas mempunyai suatu program khusus dalam mempelajari bidang kewirausahaan, sehingga ada suatu embrio young entrepreneur. Peranan lembaga pendidikan hanya sekedar menjadi fasilitator dalam memotivasi, mengarahkan dan penyedia sarana prasarana dalam mempersiapkan sarjana yang mempunyai motivasi kuat, keberanian, kemampuan serta karakter pendukung dalam mendirikan bisnis baru.

Peranan lembaga pendidikan dalam memotivasi peserta didiknya menjadi wirausahawan muda sangatlah penting. Hal ini dilihat dari beberapa pembahasan bidang kewirausahaan yang telah dikemukakan di atas. Masalahnya adalah bagaimana pihak sekolah mampu melakukan peranannya dengan benar dan mampu menghasilkan peserta didiknya yang siap berwirausaha. Peranan pihak sekolah dalam menyediakan suatu wadah yang memberikan kesempatan memulai usaha sejak masa sekolah sangatlah penting, sesuai dengan pendapat Thomas Zimmerer (2002) bahwa memulai bisnis, bisa pada saat masa sekolah berjalan, akan tetapi yang lebih penting adalah bagaimana peranan sekolah dalam hal memotivasi peserta didik untuk tergabung dalam wadah tersebut. Karena tanpa memberikan gambaran secara jelas apa saja manfaat berwirausaha, maka besar kemungkinan para siswa tidak ada yang termotivasi untuk memperdalam keterampilan berbisnisnya.

Dengan karakteristik tersebut maka sangat relevan bahwa kepala sekolah, pengawas sekolah, dan guru adalah sebagai wirausahawan sosial sejati. Kepala sekolah harus dapat mengenali kemacetan atau kemandegan sekolah yang dipimpinnya dan bagaimana mencari jalan keluar dari kemacetan atau kemandegan tersebut. Kepala sekolah harus dapat menemukan apa yang tidak berfungsi dan menecahkan berbagai masalah yang dihadapi sekolah. Kepala sekolah harus dapat meyakinkan guru dan peserta didik untuk berani melakukan perubahan ke arah yang lebih baik. Pada prestasi yang lebih tinggi kepala sekolah harus dapat membangun mata rantai sekolah menjadi sistem yang seimbang (link and match) antara wali peserta didik, guru, peserta didik, dan pengguna lulusan sekolah.

\section{METODE PENELITIN}

Rancangan penelitian ini dilakukan dengan pendekatan positivistik kuantitatif dan kualitatif secara longitudinal dengan menggunakan model riset dan pengembangan (R\&D) Borg and Gall (1989). Pendekatan 
penelitian ini juga disebut social survey design yang dipandu dengan struktur pertanyaan yang bersifat tertutup. Desain longitudinal dirancang untuk mengumpulkan data pada lebih dari satu kasus dan pada kurun waktu tertentu ketika data dikumpulkan secara kuantitatif dan kualitatif terhadap variabel yang kemudian diuji lewat pengembangan secara empirik di lapangan. Rancangan penelitian ini pada tataran selanjutnya akan menguji pengembangan model pendidikan kewirausahaan di sekolah dalam kontek karakter bangsa di wilayah kota Surakarta. Desain Research and Development $(R \& D)$ Borg \& Gall memberikan rujukan kepada peneliti bahwa untuk melakukan penelitian dan pengembangan, ditetapkan sepuluh langkah utama sebagai berikut.
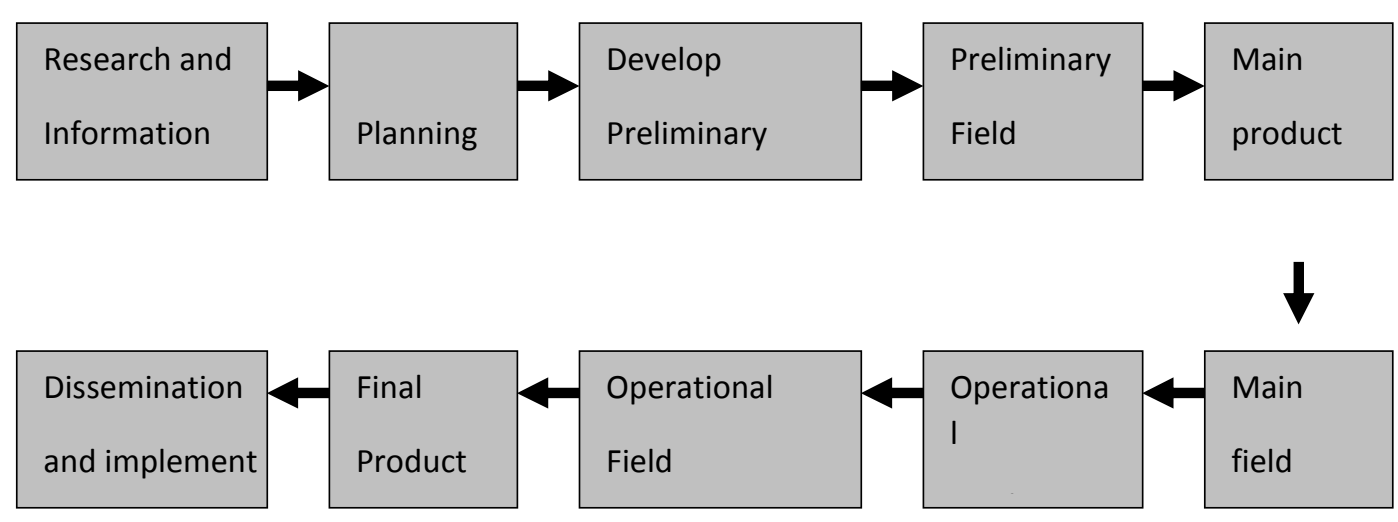

Gambar 1. Langkah-langkah R\&D Borg \& Gall (1989)

Adapun variabel yang dilibatkan dalam penelitian ini meliputi: (1) intensitas dan kebijakan pelayanan model, yang terdiri dari subvariabel: (a) partisipasi warga sekolah kejuruan; (b) partisipasi siswa sekolah kejuruan di wilayah kota Surakarta; (c) kinerja organisasi sekolah dan manajemen model; (d) sarana, vasilitas sekolah; (e) implementasi program aksi; (f) nilai manfaat model; (2) keterampilan kewirausahaan siswa sekolah kejuruan di wilayah kota Surakarta, yang terdiri dari sub variabel: (a) keakuratan kerja dengan hasil yang tepat; (b) ketepatan waktu bekerja; (c) kesempurnaan kerja dengan hasil baik; (3) efektivitas pelayanan model, yang terdiri dari sub-variabel: (a) tingkat penguasaan keterampilan usaha; (b) kualitas produk yang dihasilkan; (c) pasar produk.

Mengacu kepada tiga variabel tersebut, dapat disusun suatu model hipotetik yang memposisikan intensitas pelayanan model sebagai variabel laten eksogenous, yang terdiri dari subvariabel: (X1 partisipasi masyarakat, X2 partisipasi siswa kejuruan, X3 kinerja organisasi dan manajemen model, X4 sarana dan vasilitas, X5 implementasi program aksi, dan X6 nilai manfaat model. Keterampilan kerja siswa SMK Bopkri 1 dan 2, dan efektivitas pelayanan model sebagai variabel laten endogeneous (model struktural), yang terdiri dari subvariabel: Y1 keakuratan kerja dengan hasil yang dicapai, Y2 ketepatan waktu bekerja, Y3 kesempurnaan kerja dengan hasil baik, Y4 tingkat penguasaan keterampilan, Y5 kualitas produk, Y6 pasar produk. Selain itu, model juga menggambarkan efektivitas dan pengaruh hubungan variabel laten melalui variabel-variabel yang tampak.

Lokasi dan subjek penelitian; mempertimbangkan kemampuan dan jangkuan peneliti, sebagai lokasi model pengembangan model pendidikan kewirausahaan di sekolah dalam kontek karakter bangsa di SMK wilayah Kota Surakarta, khususnya di SMK Bopkri 1 dan SMK Bopkri 2 Surakarta. Hal ini ditetapkan karena pertimbangan teknis, sampai saat ini dana penelitian belum turun. Subyek penelitian; (a) siswa SMK yang memiliki minat dan motivasi belajar kewirausahaan dengan dibuktikan melalui tindakan need assessment. (b) warga sekolah dan instansi terkait; (c) guru pendamping pelaksana model pendidikan kewirausahaan di sekolah

Sesuai dengan tujuan ujicoba model, untuk memperoleh data dalam penelitian ini digunakan beberapa macam teknik pengumpulan data, yaitu sebagai berikut: (1) Panduan interviu dan observasi untuk menjaring 
siswa, melaksanakan identifikasi, dan need assessment dalam memilih pendidikan kewira usahaan yang dikehendaki; (2) Seperangkat modul pedoman pelaksanaan model untuk pegangan guru/tutor, modul pendidikan kewirausahaan untuk siswa; (3) seperangkat alat tes untuk mengungkap kemampuan siswa, setelah selesai mengikuti model pendidikan kewirausahaan. Analisis data kuantitatif menggunakan pendekatan deskriptif kuantitatif, sedangkan data kualitatif menggunakan pendekatan interaktif. Data yang berkaitan dengan proses pelaksanaan model kebijakan pendidikan kewirausahaan berbasis karakter, misalnya data identifikasi siswa, pengadaan sarana dan prasarana model, guru, pelaksanaan pengajaran kewirausahaan berbasis karakter, faktor lingkungan sekolah dalam pelaksana model, diperoleh sejak awal penelitian segera ditafsirkan kemudian disimpulkan maknanya.

\section{HASIL DAN PEMBAHASAN Hasil Penelitian}

Komponen pengorganisasian dalam kegiatan pendidikan kewirausahaan bagi siswa dan guru SMK Bopkri 1 dan SMK Bopkri 2 Surakarta. Untuk kelancaran dalam kegiatan pendidikan kewirausahaan perlu didukung adanya organisasi di tingkat sekolah. Organisasi ini diberi nama tim pelaksana pendidikan kewirausahaan yang pengurusnya terdiri dari para guru pendamping pendidikan kewirausahaan, unsur-unsur terkait, sebagai pelindung kegiatan. Sejumlah dua kelompok tersebut, sampai pada penelitian ini semuanya telah melaksanakan kegiatan pelatihan kepada para calon guru pendamping pendidikan kewirausahaan di setiap sekolah wilayah penelitian. Pelaksanaan pelatihan dikoordinir oleh Kepala Sekolah dengan didukung sarana dan biaya dari tim peneliti.

Berdasarkan pemantauan lapangan dan hasil pertemuan konsultasi kegiatan model pendidikan kewirausahaan di tingkat sekolah, diperoleh gambaran sebagai berikut: Sebagian besar sekolah di wilayah uji coba model kondisi keberjalanan pengorga-nisasian pendidikan kewirausahaannya dalam ketegori sangat baik 16,6 \%, kondisi baik 49,9\%, kondisi belum baik 33,2 \%. Dapat disimpulkan semua organisasi pendidikan kewirausahaan di setiap sekolah uji coba sudah berjalan dengan baik. Guna memberikan gambaran lebih jelas keberjalanan organisasi pendidikan kewirausahaan di sekolah dapat dibahas sebagai berikut: (1) keterlibatan sekolah dalam organisasi model; jumlah personil yang dilibatkan oleh para guru pendamping pendidikan kewirausahaan untuk menunjang pelaksanaan model sangat menggem-birakan. Kesediaan sekolah untuk terlibat secara langsung sebagai pengurus model pendidikan kewirausahaan mengidentifikasikan bahwa program pendidikan kewira-usahaan dapat diterima oleh sekolah. Data yang dikumpulkan oleh peneliti dari 140 responden yang dikirim ke dua sekolah menunjukkan, masyarakat sekolah menerima dan mau terlibat pada kegiatan program pendidikan kewirausahaan di sekolahnya masingmasing. Secara proporsional dapat disajikan sebagai berikut: ( 80 orang/70\% menerima dan mau terlibat), (40 orang/10\% tidak menerima dan tidak mau terlibat), (20 orang/10\% tidak tahu program tersebut); (2) manfaat adanya organisasi pelaksanaan model; Instrumen angket tentang kemanfaat organisasi model pendidikan kewirausahaan yang disebar kepada 140 responden di dua sekolah wilayah penelitian dengan dibantu interview, menunjukkan data sebagai berikut: sejumlah 110 orang $(79,66 \%)$ memberikan jawaban adanya manfaat tim/organisasi pelaksana kegiatan, sejumlah 20 orang $(12,5 \%)$ menjawab bahwa tim/organisasi pelaksana pendidikan kewirausahaan tidak dapat memberikan manfaat kepada siswa SMK, sedangkan sejumlah 10 orang $(8,33 \%)$ menjawab, bahwa mereka tidak tahu adanya tim/organisasi pendidikan kewirausahaan di sekolah; (3) efektifitas organisasi pelaksana pendidikan kewirausahaan di sekolah. Berdasarkan data yang dikumpulkan pada sejumlah 140 responden yang berada di wilayah penelitian, untuk mengetahui efektifitas organisasi pelaksana pendidikan kewirausahaan di SMK Bopkri 1 dan SMK Bopkri 2 Surakarta.

Dapat dideskripsikan bahwa efektivitas organisasi pelaksana program pendidikan kewirausahaan di sekolah bagi siswa SMK yang berada pada kategori tinggi ada 110 responden $(79,66 \%)$, pada kategori sedang ada 30 responden $(25,98 \%)$ dan tidak terdapat responden dalam ketegori rendah tidak memberikan pernyataan terhadap efektivitas keberadaan organisasi pelaksana pendidikan kewirausahaan bagi siswa di Sekolah Menengah Kejuruan. Komponen kedua dari model pendidikan kewirausahaan di sekolah yang diuji cobakan ini adalah pengembangan. Yang dimaksud pengembangan di sini adalah cara dan sistem yang diterapkan oleh tim pelaksana program atau masyarakat dalam penggalian dana yang diperlukan untuk menunjang kelancaran kegiatan pendidikan kewirausahaan di sekolahnya masing-masing. Komponen ini 
dianggap penting karena tanpa dana, mustahil program yang diintervensikan kepada sekolah ini dapat berjalan.

Pada penelitian ini telah dilakukan berbagai penyuluhan mengenai penggalian sumber dana untuk kelancaran program pendidikan kewirausahaan di sekolah. Mereka para siswa dilatih melakukan pengelolaan uang secara terbuka dan membiasakan diri untuk memanfaatkan jasa perbankan yang ada didekat sekolah. Pola ini dimaksudkan sekaligus sebagai upaya pengembangan budaya menabung di kalangan siswa atau guru.

Berbagai temuan tersebut, dapat disimpulkan bahwa pola pemanfaatan dana program pendidikan kewirausahaan sudah cukup mengarah dan positif. Hanya saja pola tersebut belum seluruhnya dilakukan oleh sekolah. Dengan demikian upaya pembinaan dan pendampingan masih sangat diperlukan untuk periodeperiode berikutnya. Sebagaimana telah diuraikan di depan, untuk memandirikan siswa SMK Bopkri 1 dan SMK Bopkri 2 Surakarta, mereka diberikan pelatihan keterampilan kerja kewirausahaan sesuai dengan bakat dan kemampuannya, setelah program tersebut berjalan selama penelitian, maka perkembangannya dapat dilaporkan sebagai berikut; dari sejumlah 120 siswa yang mengikuti pelatihan, mereka secara kelompok telah membentuk usaha prodoktif di lingkungan sekolahnya.

\section{Pembahasan}

Hasil penelitian dapat didiskusikan sebagai berikut: (1) secara keseluruhan desain penelitian model pendidikan kewirausahaan yang dikembangkan di dua sekolah sampai akhir penelitian dapat berjalan sesuai dengan tahap-tahap yang telah direncanakan; (2) kondisi di dua sekolah (SMK Bopkri 1 dan SMK Bopkri 2 Surakarta) memiliki karakteristik yang berbeda sesuai dengan kreteria yang ada di sekolah. Meskipun demikian, kedua sekolah tersebut umumnya memiliki potensi yang baik sebagai sumberdaya lingkungan sekolah yang dapat dimanfaatkan untuk pengembangan model pendidikan kewirausahaan, dalam penanganan siswa SMK untuk usaha mandiri di lingkungan tempat tinggalnya; (3) respon warga sekolah yang diwakili oleh guru pendamping terhadap program pendidikan kewirausahaan relatif tinggi, terbukti dengan adanya program pelatihan guru pendamping yang dikirim masing-masing sekolah hanya dijatah 10 orang, seluruhnya 20 orang, tetapi dikirim seluruhnya mencapai 25 orang, dan semuanya mengikuti pelatihan secara antusias sampai selesai. Keterlibatan kepala sekolah setempat saat pembukaan pelatihan pedamping guru, nampak bahwa respon warga sekolah setempat cukup baik; (4) jumlah siswa yang berhasil dijaring dalam penelitian berjumlah 140 orang. Penyebarannya menunjukkan; SMK Bopkri 180 siswa, dan SMK Bopkri 2 Surakarta 60 siswa. Angka ini berkorelasi dengan karakteristik sekolah. Semakin maju sekolah akan semakin memiliki kesadaran dan motivasi terhadap program kegiatan yang ditawarkan, dan sebaliknya; (5) tampaknya dari segi sosialisasi kegiatan model pendidikan kewirausahaan sampai akhir penelitian ini, dapat disimpulkan bahwa baik di SMK Bopkri 1 dan SMK Bopkri 2 Surakarta sama-sama memiliki tingkat kelancaran baik.

Hal ini didukung oleh fakta bahwa dari sejumlah guru pendamping di masing-masing sekolah telah berhasil merekrut warga sekolah yang bersedia menjadi pengurus kegiatan model pendidikan kewirausahaan bagi siswa di Sekolah Menengah Kejuruan. Mengenai temuan tentang dampak program pendidikan kewirausahaan, memang belum maksimal, hal ini disebabkan adanya keterbatasan waktu dan dana yang tersedia, mengakibatkan rencana kegiatan agak terganggu.

\section{KESIMPULAN DAN SARAN \\ Kesimpulan}

1. Beberapa komponen pendidikan kewirausahaan di Sekolah Menengah Kejuruan yang dikembangkan dalam penelitian ini (komponen pengorganisasian, pendanaan, program aksi pendidikan kewirausahaan, evaluasi dan tindak lanjut) telah dijalankan oleh warga sekolah dengan menerapkan prinsip-prinsip partisipatif, yaitu mendorong warga sekolah untuk ikut berpartisipasi proses pendidikan kewirausahaan di Sekolah Menengah Kejuruan. 
2. Tingkat keberjalanan komponen pengorganisasian pendidikan kewirausahaan pada umumnya sudah masuk kategari baik, dan dari hasil penelitian ini menunjukkan grafik yang meningkat. Hal ini berarti komponen pengorganisasian berfungsi cukup efektif.

3. Keberjalanan pengembangan pendanaan untuk menunjang program pendidikan kewirausahaan di setiap sekolah wilayah penelitian umumnya telah berjalan sesuai dengan kreativitas dan kesadaran masingmasing guru pendamping, tetapi dari segi kestabilan usaha dan pemanfaatannya, umumnya masil lemah, sehingga hasilnya juga sangat bervariasi. Berarti efektivitas komponen pengembangan pendanaan masih perlu ditingkatkan melalui pembinaan lebih lanjut.

4. Efektivitas pengembangan partisipasi program pendidikan kewirausahaan bagi siswa di Sekolah Menengah Kejuruan yang dilakukan oleh warga sekolah, baik secara kuantitatif maupun kualitatif menggambarkan hasil yang cukup positif. Komponen ini meskipun masih ada kekurangan namun menunjukkan adanya kemajuan yang berarti dari hasil penelitian ini. Berarti komponen ini dapat dijalankan oleh warga sekolah, khususnya siswa yang telah mengikuti pelatihan program pendidikan kewirausahaan.

6. Model pendidikan kewirausahaan dapat dikembangkan lebih lanjut sebagai salah satu alternatif penanganan usaha-usaha kesejahteraan sosial di masyarakat, khususnya para generasi muda yang masih sekolah. Model ini dalam beberapa hal mampu mendorong generasi muda lebih mandiri dalam mengatasi persoalan-persoalan sosial di masyarakat, sementara di pihak lain siswa SMK sendiri yang semula kurang diperhatikan, dapat dibina menjadi lebih produktif dan mandiri, sehingga sangat berarti bagi dirinya, keluarga, maupun masyarakat di sekitarnya.

\section{Saran}

1. Pendidikan kewirausahaan yang dikembangkan oleh tim peneliti STIE AUB ini, perlu direplikasikan ke sekolah lain yang lebih luas atas dukungan pihak pemerintah dengan penyederhanaan yang dipandang perlu, sehingga hasilnya nanti dapat digunakan sebagai bahan masukan untuk kebijakan pemerintah.

2. Melihat pentingnya program pendidikan kewirausahaan, dan kenyataannya tidak setiap pembina atau petugas sokolah memahami konsep siswa di sekolah dan cara operasionalnya, maka pemerintah perlu menindaklanjuti program pendidikan kewirausahaan bagi para guru pendamping, baik dalam skala sekolah maupun tingkat wilayah atau kedaerahan.

3. Peran instansi terkait ditingkat Dinas Pendidikan Kota Surakarta dan sekolah, yang diawali dengan baik, sebagai implementasi dari peran tersebut dengan mengajukan berbagai usulan program nyata baik bersifat jangka pendek maupun jangka panjang, sehingga program model pendidikan kewirausahaan ini dapat berhasil secara optimal dilingkungan Sekolah Menengah Kejuruan.

\section{DAFTAR PUSTAKA}

Arismunandar. (2006). Pengembangan Kewirausahaan Sekolah, Direktorat Tenaga Kependidikan Departemen Pendidikan Nasional, Jakarta.

Buchari, (2006). Kewirausahaan Sekolah Berbasis Kreativitas dan Inovasi, Direktorat Tenaga Kependidikan Departemen Pendidikan Nasional, Jakarta.

Binsar A. Hutabarat. (2010). Karakter bangsa, dulu dan kini, dari file:///G/ karakter_bangsa_dulu_dan_kini.html. diunduh 27 April 2010.

Borg R Walter, Gall Mredith D, (1989), Educational research, an intruduction, Routledge, New York. Ogdan, Robert C, Biklen, Knopp Sari, (1982), Qualitative Research fo Eduactin, An Int

Disarikan dari: Depdiknas. 2007. Kewirausahaan Sekolah. materi diklat pembinaan komptetensi calon kepala sekolah/kepala sekolah). Jakarta.

FIET, J.O. (2000), The theoretical side of teaching entrepre-neurship, Journal of Business Venturing 16, 124.

Hakim, Rusman. (1998). Dengan Berwiraswasta Menepis Krisis: Konsep Membangun Masyarakat Entrepreneur Indonesia, Alex Media Komputindo, Jakarta. 
Hisrich \& Peters (2002), It's not an exact science: teaching entrepreneurship in Northern Ireland, Journal of Education \& Training, 48(5), pp. 322-335, Emerald Group Publishing.

Henry, C, Hill, F, and Leitch, C., (2005), Entrepreneurship education and training: can entrepreneurship be taught? Part I, Journal of Education \& Training, Vol. 47 No.2, pp. 98-111.

Heinonen, J., and Poikkijoki, S.A., (2006), An entrepreneurial-directed approach to entrepreneurship education: mission impossible?, Journal of Management Development, Vol. 25 No.1, pp. 80-94.

Hers. Richard H. et al. (1980). Model of moral education: An Appraisal. New York: Longman Inc.

Kao (1991), The pedagogical side of teaching entrepreneurship, Journal of Business Venturing 16, 101117.

Kao, John, (1989), Entrepreneurship, Creativity \& Organization, Harvad Business School, Prentice Hall, Englewood, New Jersey.

Ki Tyasno Sudarto. (2007). "Pengembangan nilai-nilai luhur budi pekerti sebagai karakter bangsa" dari file/H./Pengembangan/20 Nilai-nilai/20Luhur/20Budi/ Pekerti. Diakses 12 Maret 2010.

Louck, Kenneth, (1991). Training Entrepreneurs for Small Business Creation: Lessons from Exprience, Manajemen Development Series, No. 26, International Labour Office, Geneva.

Maksum dan Luluk YR. (2004). Paradigma pendidikan universal di era modern dan post modern, Yogyakarta: Penerbit Sarasin.

Magnis Suseno Frans. (1987). Etika dasar; masalah-masalah pokok filsafat moral, Jakarta: Penerbit Kanisius.

Mas'ud Machfoedz (2004). Iklim Organisasi Kreatif, Manajemen USAHAWAN Indonesia, No. 09/TH XXXIII September 2004.

Patel, V. G., (1985), Entrepreneurship Development Programme in India and Its Relevance Developing Countries, Entrepre-neurship Development Institute of India, Ahmedabad, in Louck: Training Entrepreneurs for Small Business Creation.

Rusman, Hakim, (1998). Dengan Berwiraswasta Menepis Krisis: Konsep Membangun Masyarakat Entrepreneur Indonesia, Alex Media Komputindo, Jakarta.

Ropke, (1989), Introduction: The Study of Business Entrepre-neurship in Comparative Perspective in: TT. Auang (ed); Burnese entrepreneurship Creative Response in the Colonial Economy, Wiesbaden, Franz Steiner Verdagg, pp vi-xvi.

Siagian, Salim, (1995), Kewirausahaan Indonesia dengan Semangat 17-8-45, Departemen Koperasi dan Pembinaan Pengusaha Kecil, Puslatkop dan PK, Jakarta.

Soersarsono Wijandi. (1987). Pengantar Kewirauahaan. Bandung: Sinar Baru.

Steven C Brandt. (1991). Sepuluh tahapan menjadi wirausahawan tangguh. Semarang: Dahara Prize.

Smith, A.J. (2006), Embedding new entrepreneurship programmes in UK higher education institutions: Challenges and consi-derations, Education \& Training Vol. 48 No. 8/9, pp. 555-567.

Suparman Sumohamijaya (1980). Kewirausahaan yang berproses. Jakarta: PT. Gramedia Widiasarana Indonesia.

Silvia Herawaty, (1998), Kewirausahaan di Indonesia, Departemen Koperasi dan Pembinaan Pengusaha Kecil, Puslatkop dan PK, Jakarta.

Suyana. (2003). Pengembangan Kewirausahaan Sekolah, Direktorat Tenaga Kependidikan Departemen Pendidikan Nasional, Jakarta.

Thoby Mutis. (1995). Kewirausahaan yang berproses. Jakarta: PT. Gramedia Widiasarana Indonesia. . (2007). Kewirausahaan Sekolah Berbasis Kreativitas dan Inovasi, Direktorat Tenaga Kependidikan Departemen Pendidikan Nasional, Jakarta. 
Tarsis Tarmudji. (1987). Pengantar Kewirausahaan. Bandung: Sinar Baru.

Thomas Zimmers, (2001), Critical evaluation of two models for entrepreneurial education, An improved model through integration, International Journal of Educational Management, Vol 19 No.5, pp. 413427. 